\title{
SiRNA directed against NF-кB inhibits mononuclear macrophage cells releasing proinflammatory cytokines in vitro
}

\author{
CHUNTING WU $^{1}$, JIAHUI ZHAO ${ }^{2}$, GUANGFA ZHU ${ }^{1}$, YAN HUANG ${ }^{1}$ and LIYAN JIN ${ }^{1}$ \\ Departments of ${ }^{1}$ Respiratory and Critical Care Medicine; ${ }^{2}$ Urology, Beijing Anzhen \\ Hospital, Capital Medical University, Beijing 100029, P.R. China
}

Received October 9, 2016; Accepted May 26, 2017

DOI: $10.3892 / \mathrm{mmr} .2017 .7715$

\begin{abstract}
Acute lung injury (ALI) is a condition of acute respiratory failure, characterized by diffuse pulmonary infiltrates and severe hypoxemia. During ALI, the acute phase of inflammation induces the recruitment of activated inflammatory cells, including macrophages and lymphocytes, to the damaged lesions. Nuclear factor (NF)- $\kappa \mathrm{B}$ is a key protein in many signal transduction pathways, over-activation of which is followed by an approach of inflammation cells and release of pre-inflammation cytokines. The aim of the present study was to explore the effect of NF- $\kappa$ B P65 siRNA retroviruses on the activation of NF- $\mathrm{kB}$ signaling pathway and release of pro-inflammatory cytokines in THP-1 cells. In the present study, reverse transcription-quantitative polymerase chain reaction (RT-qPCR) and western blotting were used to detect the NF- $\mathrm{KB}$ p 65 mRNA and protein expression at different times in THP-1 cells infected by $\mathrm{p} 65$ siRNA retroviruses. The results revealed that p65 siRNA retroviruses could significantly inhibit the expression levels of NF- $\mathrm{kB}$ p65 mRNA and protein at different times. In addition, to further investigate the effect of p65 siRNA retroviruses on the pro-inflammatory cytokines release stimulated by LPS, the expression of IL- $1 \beta$ in THP- 1 cells and TNF- $\alpha$ in THP-1/M cells was also detected using RT-qPCR and ELISA. As a result, the level of released proinflammatory cytokine interleukin- $1 \beta$ and tumor necrosis factor- $\alpha$ stimulated was significantly inhibited at different times infected by p65 siRNA retroviruses, while increased at different times infected by siControl retroviruses in THP-1 and THP-1/M cells stimulated by LPS. In summary, the present study demonstrated that p65 siRNA retroviruses could suppress the activation of NF- $\mathrm{\kappa B}$ signal pathway and release of pro-inflammatory cytokines in THP-1 cells which provided
\end{abstract}

Correspondence to: Dr Guangfa Zhu, Department of Respiratory and Critical Care Medicine, Beijing Anzhen Hospital, Capital Medical University, 2 Anzhen Road, Beijing 100029, P.R. China E-mail: guangfazhu2006@163.com

Key words: nuclear factor- $\kappa \mathrm{B}$ p65, small interference RNA, retrovirus, monocyte macrophage, inflammation a clinically plausible method to inhibit the inflammation for ALI/ARDS utilizing RNA interference technology.

\section{Introduction}

Acute lung injury (ALI) and its severe form, acute respiratory distress syndrome (ARDS), is a clinical syndrome of severe lung failure defined by acute onset, bilateral opacities on the chest radiograph, respiratory failure not fully explained by cardiac failure or fluid overload, and a ratio of arterial oxygen to inspired oxygen of $<200 \mathrm{mmHg}$ with a positive end-expiratory pressure of $\geq 5 \mathrm{~cm} \mathrm{H}_{2} \mathrm{O}$. ALI/ARDS is characterized by a disruption of the endothelium and alveolar injury, resulting in an uncontrolled inflammatory response, including increasing release of reactive oxygen species (ROS), inflammatory cytokines, protein content and neutrophil accumulation. Despite numerous studies that have been performed in recent years, the underlying mechanisms of ALI/ARDS remain unclear, there are no effective therapies for the disease and the mortality rate of intensive care patients with ALI/ARDS is as high as $40-60 \%$, which is a problem in respiratory medicine (1). Multiple factors may be involved in the increased vascular permeability, including endothelium injury, increased levels of pro-inflammatory cytokines TNF- $\alpha$ (tumor necrosis factor alpha), interleukin 1 (IL-1), or IL-6 and IL-8, and endovascular occlusion associated with the accumulation of erythrocytes with reduced deformability, leukocytes, and platelets (2).

Nuclear factor (NF) $-\mathrm{kB}$ is a key protein in numerous signal transduction pathways, the overactivation of which followed by activation and the response of inflammatory cells serves an important role in ALI/ARDS. The mammalian NF- $\kappa \mathrm{B}$ family consists of p65 (or RelA), RelB, c-Rel, p50 (or NF-kB1), and p52 (or NF-kB2), which bind to the $\kappa \mathrm{B}$ sites in the DNA of their target genes as homo- or heterodimers through the conserved Rel homology domain (RHD) (3). RNA interference is a specific and effective gene silencing technology, which is able to specifically inhibit target gene expression and reduce the corresponding protein level. The present study was primarily aimed at observing the NF- $\mathrm{KB}$ p 65 silencing effect through small interfering RNA (siRNA) targeted to the NF- $\kappa \mathrm{B}$ p65 gene, which prevents monocyte and phorbol myristate acetate (PMA)-induced THP-1 macrophages treated by lipopolysaccharide (LPS) from releasing IL-1 $\beta$ and TNF- $\alpha$, providing a basis for novel treatments for ALI/ARDS. 


\section{Materials and methods}

Cell culture and plasmids. The pSUPER. retro. neo (VEC -PRT-0003 linear) plasmid DNA and the retrovirus packaging cell line 293A were kindly provided by Dr Yang Yizeng (NIH Center for Molecular Studies in Digestive and Liver Diseases, Perelman School of Medicine, University of Pennsylvania, Philadelphia, PA, USA). The human monocyte THP-1 cell line was kindly provided by the Department of Pharmacology, Xuanwu Hospital of Capital Medical University (Beijing, China), and the NIH3T3 cell line was provided by Institute of Neurology, Basic Medical Sciences of Peking University Health Science Center (Beijing, China). THP-1 and NIH3T3 cell lines were cultured in RPMI 1640 medium supplemented with $10 \%$ fetal bovine serum (FBS) and penicillin (100 U/ml) streptomycin $(100 \mu \mathrm{g} / \mathrm{ml})$. 293A cells were cultured in Dulbecco's modified Eagle's medium supplemented with 10\% FBS and penicillin $(100 \mathrm{U} / \mathrm{ml})$ streptomycin $(100 \mu \mathrm{g} / \mathrm{ml})$. DMEM and RPMI-1640 medium were purchased from Hyclone (GE Healthcare Life Sciences, Logan, UT, USA), and FBS was purchased from Gibco (Thermo Fisher Scientific, Inc. Waltham, MA, USA).

Two looped specific NF- $\mathrm{B}$ P65 siRNA sequences and one scramble control sequence (list in Table I) were synthesized by Beijing Sunbiotech Co., Ltd. (Beijing, China) and ligated into pSUPER.retro.neo vector according to the protocol described in a previous study (4).

The NF- $\kappa$ B p65 siRNA vectors were transfected into 293A package cells using Lipofectamine2000 ${ }^{\mathrm{TM}}$ (Invitrogen; Thermo Fisher Scientific, Inc., Waltham, MA, USA) according to the manufacturer's instructions, and the virus suspension was collected following 24,48 or $72 \mathrm{~h}$. Virus titration was performed with NIH3T3 cells. The viral titer was $3.72 \times 10^{6}$ colony forming units $(\mathrm{CFU}) / \mathrm{ml}$ for p65 siRNA1, $3.56 \times 10^{6} \mathrm{CFU} / \mathrm{ml}$ for p65 siRNA2 and $3.66 \times 10^{6} \mathrm{CFU} / \mathrm{ml}$ for p65 si-Control.

Reverse transcription-quantitative polymerase chain reaction $(R T-q P C R)$. Total RNAs were exacted from the cell lines at $80-90 \%$ confluence by using TRIzol (Invitrogen; Thermo Fisher Scientific, Inc.). A total of $1 \mu \mathrm{g}$ RNA was reverse transcribed using a RevertAid first strand cDNA synthesis kit (Thermo Fisher Scientific, Inc.). The qPCR was performed using QuantiTect SYBR Green PCR kit (Qiagen, Inc., Valencia, CA, USA) according to the manufacturer's protocol. All the primers (listed in Table II) were obtained from Sanbio B.V. (Uden, The Netherlands). All the PCR reactions were initiated with incubation at $94^{\circ} \mathrm{C}$ for $2 \mathrm{~min}$, followed by 29 cycles of $94^{\circ} \mathrm{C}$ for $30 \mathrm{sec}, 58^{\circ} \mathrm{C}$ for $30 \mathrm{sec}$ and $72^{\circ} \mathrm{C}$ for $2 \mathrm{~min}$. Reactions were finished with a $72^{\circ} \mathrm{C} 10 \mathrm{~min}$ extension. Data were normalized using the $2^{-\Delta \Delta \mathrm{Cq}}$ method (5).

Western blotting. Total protein were isolated from cultured cells by $300 \mu \mathrm{l}$ ice cold lysis buffer containing $1 \% \mathrm{NP}-40,50 \mathrm{mmol} / \mathrm{l}$ Tris (pH 7.4), $150 \mathrm{mmol} / 1 \mathrm{NaCl}, 0.1 \%$ SDS, $0.5 \%$ deoxycholate, $200 \mu \mathrm{g} / \mathrm{ml}$ phenylmethanesulfonyl fluoride and $50 \mu \mathrm{g} / \mathrm{ml}$ aprotinin. Insoluble materials were removed by ultracentrifugation at $15,000 \mathrm{x} \mathrm{g}$ for $30 \mathrm{~min}$ for $4^{\circ} \mathrm{C}$. The concentration of the extracted protein was measured spectrophotometrically with Coomassie G-250. Clarified protein lysates $(50 \mu \mathrm{g})$ were electrophoretically resolved on denaturing SDS-PAGE (8-12\%). The proteins were transferred onto polyvinylidene fluoride membranes using a wet transfer method following PAGE, and subsequently blocked with $3 \%$ bovine serum albumin (Santa Cruz Biotechnology, Inc., Dallas, TX, USA) for $1 \mathrm{~h}$ at room temperature and washed with Tris-buffered saline and Tween-20 three times. Antibodies specific for NF- $\kappa \mathrm{B}$ p65 (mouse anti-human IgG; 1:500; cat. no. sc-8008) and GAPDH (mouse anti-human IgG; 1:10,000; cat. no. sc-47724) were used to probe membranes for $2 \mathrm{~h}$ at room temperature, followed by peroxidase-conjugated secondary antibodies (goat anti-mouse IgG; 1:5,000; cat. no. sc-3697) for $1 \mathrm{~h}$ at room temperature and enhanced chemiluminescence detection (Sigma-Aldrich; Merck KGaA, Darmstadt, Germany). All primary and secondary antibodies were obtained from Santa Cruz Biotechnology, Inc. For quantification of band intensity, appropriate films were scanned and band densities were determined using Quantity One software (version 4.6.6; Bio-Rad Laboratories, Inc., Hercules, CA, USA), normalized against GAPDH, and presented as a ratio of control.

ELISA. Secretory levels of IL-1 $\beta$ and TNF- $\alpha$ in culture supernatants were determined by the Quantikine ELISA kit (R\&D Systems, Inc. Minneapolis, MN, USA, cat. nos. DLB50 and DTA00C). The color generated was determined by measuring the OD at $450 \mathrm{~nm}$ using a spectrophotometric microplate reader. A standard curve was run on each assay plate using serial dilutions of recombinant IL- $1 \beta$ and TNF- $\alpha$. The experiment was repeated three times and results were presented as the mean value.

Statistical analysis. Data are presented as the mean \pm standard deviation. All data analyses were performed using SPSS software version 13.0 for Windows (SPSS, Inc., Chicago, IL, USA). One-way analysis of variance (ANOVA) and independent-samples t-tests were conducted. Tukey's test was used for post-hoc testing following the ANOVA. All experiments were performed at least three times with similar results. $\mathrm{P}<0.05$ was considered to indicate a statistically significant difference.

\section{Results}

Inhibition of mRNA expression by p65 siRNA retroviruses. In a previous study, the authors successfully constructed the p65 siRNA retroviruses using gene recombination technology. In the present study, the effect of p65 siRNA retroviruses on the expression of $\mathrm{NF}-\kappa \mathrm{B}$ p 65 mRNA in THP-1 cells was investigated. Fig. 1A revealed the levels of p65 mRNA at $0,4,8,12$ and $24 \mathrm{~h}$ following infection with p65 siRNA retroviruses, as measured by RT-qPCR. Statistical analysis demonstrated that the p65 mRNA expression levels were significant reduced at 4, 8, 12 and $24 \mathrm{~h}$ following infection with p65 siRNA1 and p65 siRNA2 retroviruses, while no significant difference in THP-1 cells infected with siControl retroviruses (Fig. 1B).

Inhibition of protein expression by p65 siRNA retroviruses. To further investigate the inhibitory effects of p65 siRNA retroviruses on the $\mathrm{NF}-\kappa \mathrm{B}$ signaling pathway, the expression of NF- $\mathrm{B}$ p 65 protein was detected using western blot 
Table I. siRNA targeting human nuclear factor- $\kappa \mathrm{B}$ p65 and the siControl sequence.

\begin{tabular}{ll}
\hline Group & \multicolumn{1}{c}{ Sequence } \\
\hline siRNA1 & 5'-GATCCCCAGCATCCCAGGCGAGAGGATTCAAGAGATCGTAGGGTCCGCTCTCCTTTTTTA-3' \\
siRNA1 & 3'-GGGTCGTAGGGTCCGCTCTCCTAAGTTCTCTAGCATCCCAGGCGAGAGGAAAAAATTCGA-5' \\
& 5'-GATCCCCGGACATATGAGACCTTCAATTCAAGAGATTGAAGGTCTCATATGTCCTTTTTA-3' \\
siControl & 3'-GGGCCTGTATACTCTGGAAGTTAAGTTCTCTACTTCCAGAGTATACAGGAAAAATTCGA-5' \\
& 5'-GATCCCCAACGAGTGTGCCTACATCCTTCAAGAGAGGATGTAGGCACACTCGTTTTTTA-3' \\
& 3'-GGGTTGCTCACACGGATGTAGGAAGTTCTCTCCTACATCCGTGTGAGCAAAAAAATTCGA-5'
\end{tabular}

siRNA, small interfering RNA.

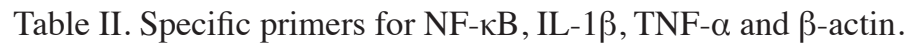

\begin{tabular}{|c|c|c|c|}
\hline Gene & Direction & Primer sequence $\left(5^{\prime}-3^{\prime}\right)$ & Size (bp) \\
\hline $\mathrm{NF}-\kappa \mathrm{B}$ p65 & Forward & GTGTTCACAGACCTGGCATCC & $230 \mathrm{bp}$ \\
\hline $\mathrm{NF}-\kappa \mathrm{B}$ p65 & Reverse & TCCGCAATGGAGGAGAAGTCT & \\
\hline IL-1 $\beta$ & Forward & TGTACCTGTCCTGCGTGTTG & $316 \mathrm{bp}$ \\
\hline IL-1 $\beta$ & Reverse & GCCCTAGGGATTGAGTCCAC & \\
\hline TNF- $\alpha$ & Forward & CССАТССССААТААСААТССА & $262 \mathrm{bp}$ \\
\hline TNF- $\alpha$ & Reverse & GAGCTCTGCAGTTGGGACAGT & \\
\hline$\beta$-actin & Forward & GGGAAATCGTGCGTGACAT & $385 \mathrm{bp}$ \\
\hline$\beta$-actin & Reverse & TCAGGAGGAGCAATGATCTTG & \\
\hline
\end{tabular}

NF- $\kappa B$, nuclear factor- $\kappa \mathrm{B}$; IL, interleukin; TNF- $\alpha$, tumor necrosis factor- $\alpha$.

A

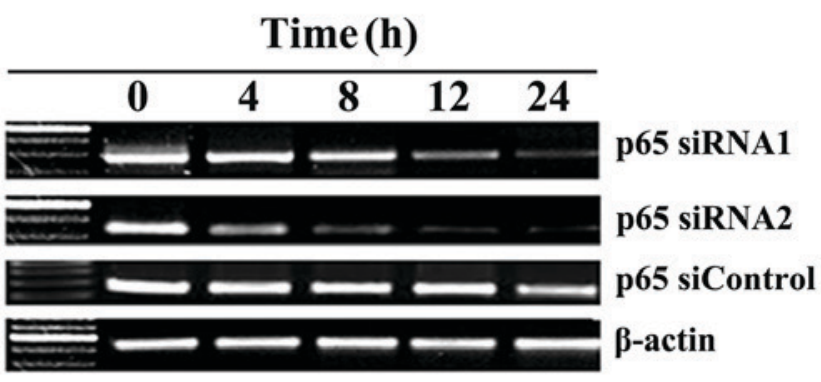

B

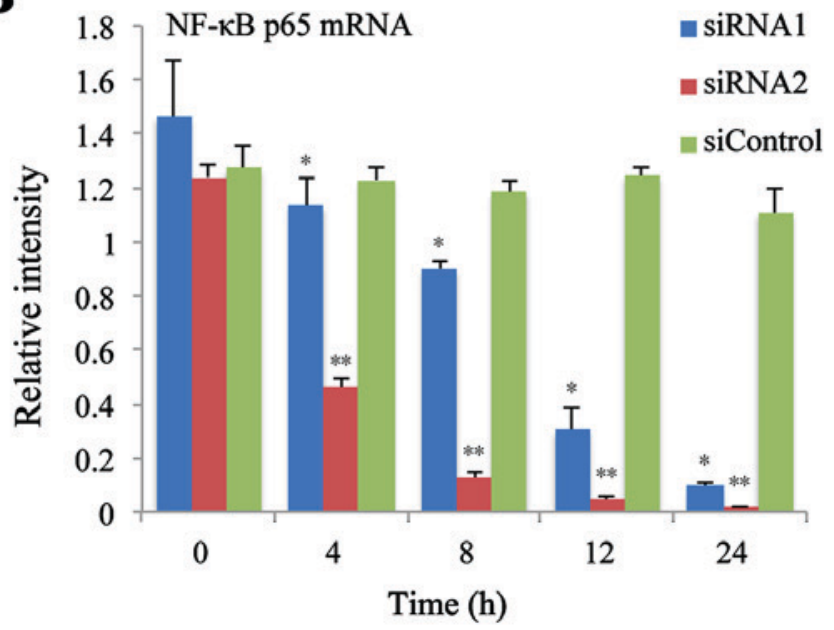

Figure 1. Inhibitory effects of p65 siRNA retroviruses on p65 mRNA expression levels. (A) The expression levels of p65 mRNA at different time in THP-1 cells transfected with p65 siRNA retroviruses were measured by reverse transcription-quantitative polymerase chain reaction. (B) The mRNA expression levels of p65 were significantly reduced at $4,8,12$ and $24 \mathrm{~h}$ in THP-1 cells transfected with p65 siRNA1 and p65 siRNA2, while no significantly difference transfected with siControl retroviruses. Data are expressed as the mean \pm standard deviation $(\mathrm{n}=5)$. ${ }^{*} \mathrm{P}<0.05,{ }^{* *} \mathrm{P}<0.01$ vs. 0 h. siRNA, small interfering RNA; NF- $\kappa B$, nuclear factor- $\kappa B$.

analysis. The level of $\mathrm{p} 65$ protein in THP-1 cells infected with p65 siRNA retroviruses at $0,4,8,12,24,48$ and $72 \mathrm{~h}$ was presented in Fig. 2A. Statistical analysis revealed that the protein expression levels of p65 in THP-1 cells was significantly decreased from $12 \mathrm{~h}$ to $72 \mathrm{~h}$ following infection with p65 siRNA1 retroviruses, while decreased from $8 \mathrm{~h}$ to $72 \mathrm{~h}$ following infection with p65 siRNA2 retroviruses. There was no significant difference of $\mathrm{p} 65$ protein expression at different time in THP-1 cells following infection with siControl retroviruses (Fig. 2B). 
A

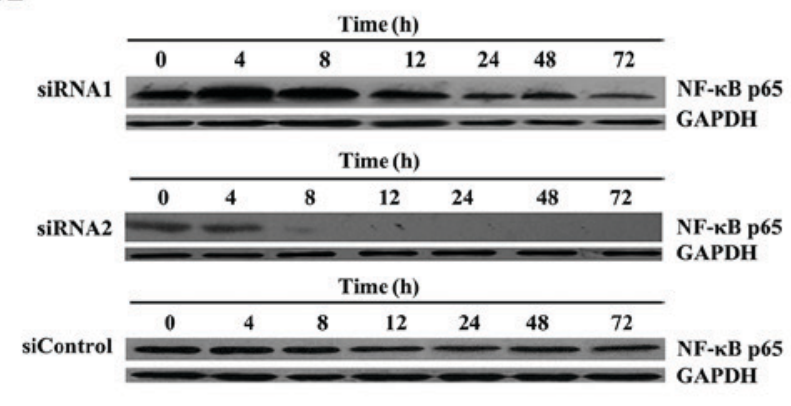

B

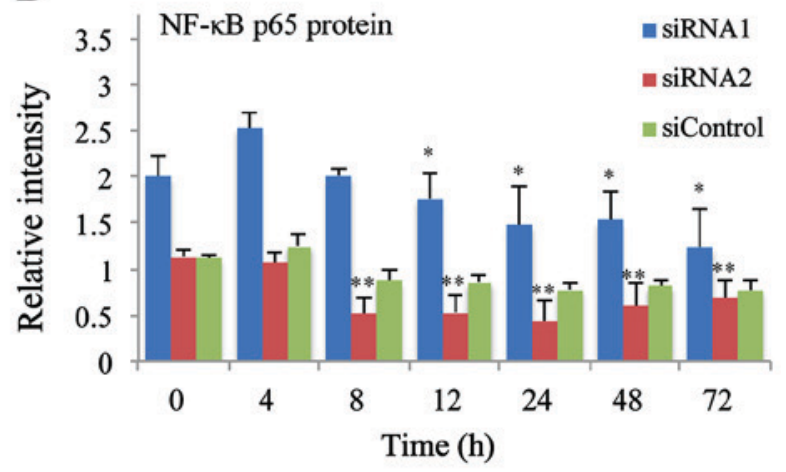

Figure 2. Inhibitory effects of $\mathrm{p} 65$ siRNA retroviruses on p65 protein expression levels. (A) The expression levels of p65 protein at $0,4,8,12,24,48$ and $72 \mathrm{~h}$ in THP-1 cells transfected with p65 siRNA retroviruses were measured by western blot analysis. (B) The protein expression levels of p65 were significantly reduced at 12, 24, 48 and $72 \mathrm{~h}$ in THP-1 cells following transfection with p65 siRNA1 retroviruses, while decreased at 8, 12, 24, 48 and $72 \mathrm{~h}$ following transfection with p65 siRNA2 retroviruses. There was no significant difference of protein expression at different times in THP-1 cells infected with siControl retroviruses. Data are expressed as the mean \pm standard deviation $(n=5)$. ${ }^{*} \mathrm{P}<0.05,{ }^{* * *} \mathrm{P}<0.01$ vs. 0 h. siRNA, small interfering RNA; NF- $\mathrm{kB}$, nuclear factor- $\kappa \mathrm{B}$.

A

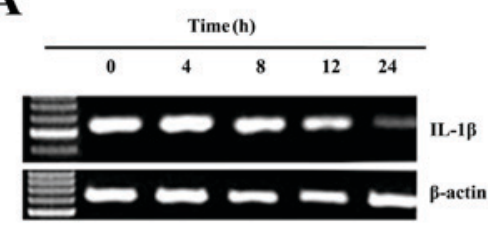

C

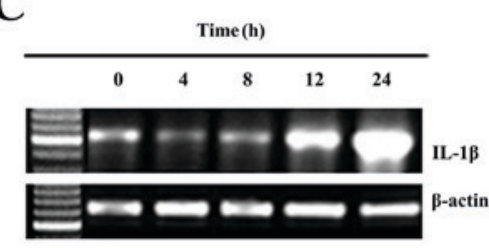

$\mathbf{B}$

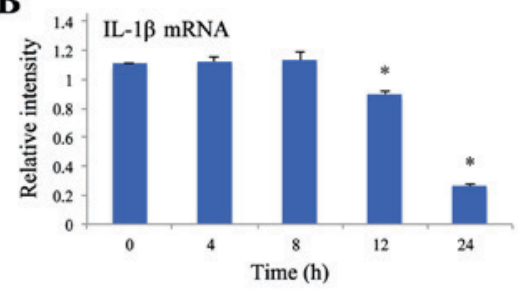

$\mathbf{D}$

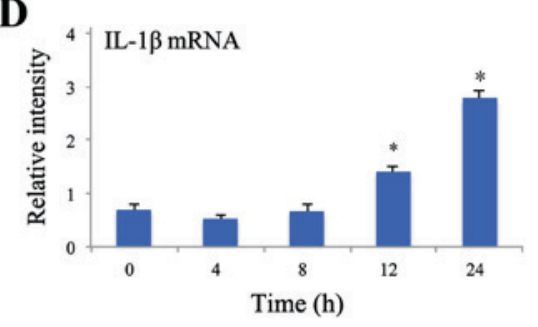

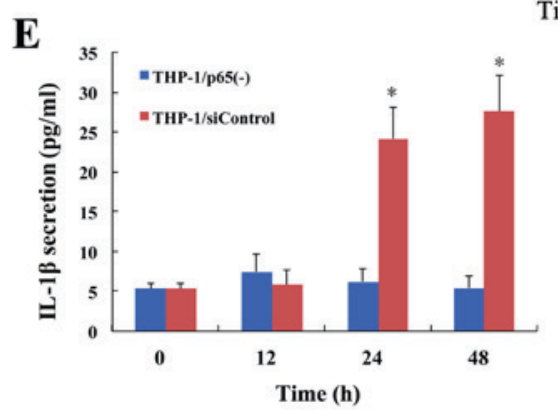

Figure 3. Inhibitory effects of p65 siRNA retroviruses on IL-1 $\beta$ expression, as assessed by RT-qPCR and ELISA in THP-1/p65(-) and THP-1/siControl cells stimulated by LPS. (A) The THP-1/p65(-) cells were treated with LPS $(0.1 \mathrm{~g} / \mathrm{ml})$ and mRNA levels of IL-1 $\beta$ at $0,4,8,12$ and $24 \mathrm{~h}$ were measured by RT-qPCR (B) The mRNA expression levels of IL- $1 \beta$ were significantly reduced at $12 \mathrm{~h}$ and $24 \mathrm{~h}$ compared with at $0 \mathrm{~h}$. Data are expressed as the mean \pm standard deviation $(\mathrm{n}=5)$. (C) The THP-1/siControl cells were treated with LPS $(0.1 \mathrm{~g} / \mathrm{ml})$ and mRNA levels of IL-1 $\beta$ at $0,4,8,12$ and $24 \mathrm{~h}$ were measured by RT-qPCR (D) The mRNA expression levels of IL-1 $\beta$ were significant increased at $12 \mathrm{~h}$ and $24 \mathrm{~h}$ compared with at $0 \mathrm{~h}$. Data are expressed as the mean \pm standard deviation ( $\mathrm{n}=5$ ). (E) Inhibitory effect of p65 siRNA retroviruses on IL-1 $\beta$ secretion assessed by ELISA in THP-1 cells stimulated by LPS. TheTHP-1/p65(-) and THP- $1 / \mathrm{siC}$ (trol cells were treated with LPS $(0.1 \mathrm{~g} / \mathrm{ml})$ and levels of IL-1 $\beta$ at $0,12,24$ and $48 \mathrm{~h}$ was measured by ELISA. Treatment with LPS resulted in a significant increase in the secretion of IL- $1 \beta$ at $24 \mathrm{~h}$ and $48 \mathrm{~h}$ in THP-1/siControl cells. However, the secretion of IL-1 $\beta$ sustained a lower level and there was no significant difference at $0,12,24$ and $48 \mathrm{~h}$ in THP-1/p65(-) cells stimulated by LPS. Data are expressed as the mean \pm standard deviation $(\mathrm{n}=5)$. ${ }^{*} \mathrm{P}<0.05 \mathrm{vs}$. 0 h. THP-1/p65(-) cells, THP-1 cells infected with p65 siRNA2 retrovirus. THP-1/siControl cells, THP-1 cells infected with siControl retroviruses. siRNA, small interfering RNA, IL, interleukin; RT-qPCR, reverse transcription-quantitative polymerase chain reaction; LPS, lipopolysaccharide.

The RT-qPCR and western blot analysis revealed that the siRNA2 was the most effective in decreasing p65 expression, so p65 siRNA2 was used for further research.
Inhibition of pre-inflammation cytokine $I L-1 \beta$ release by p65 siRNA retroviruses. In order to investigate the effect of p65 siRNA retroviruses on the pro-inflammatory cytokines 
A

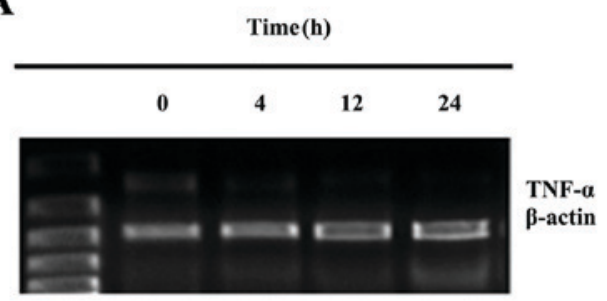

C

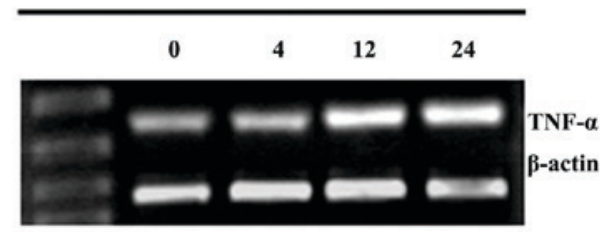

B

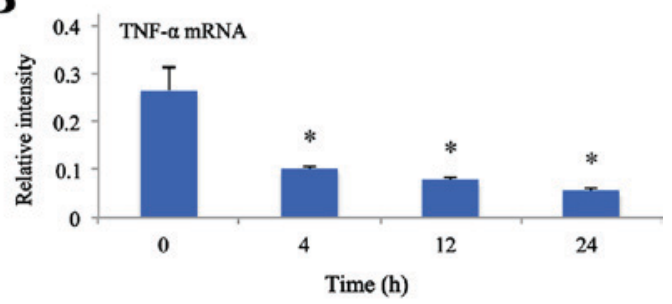

D

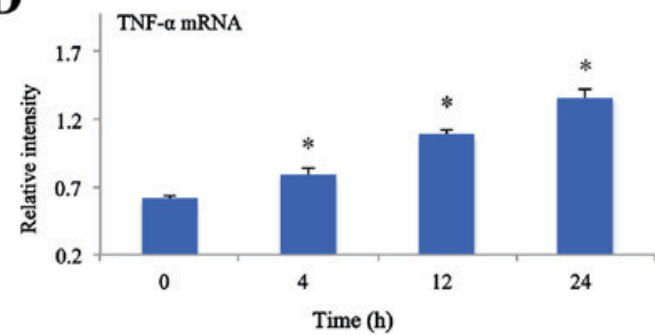

$\mathbf{E}$

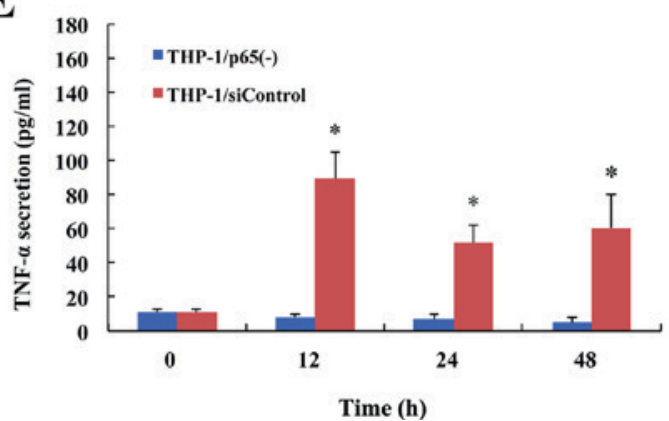

Figure 4. Inhibitory effect of p65 siRNA retroviruses on TNF- $\alpha$ expression assessed by RT-qPCR and ELISA in THP-1 cells stimulated by LPS. (A) The THP-1/siControl cells were treated with LPS $(0.1 \mathrm{~g} / \mathrm{ml})$ and mRNA levels of TNF- $\alpha$ at $0,4,12$ and $24 \mathrm{~h}$ were measured by RT-qPCR. (B) The mRNA expression levels of TNF- $\alpha$ were significant reduced at 4,12 and $24 \mathrm{~h}$ compared with at $0 \mathrm{~h}(\mathrm{n}=4)$. (C) The THP- $1 /$ siControl cells were treated with LPS $(0.1 \mathrm{~g} / \mathrm{ml})$ and mRNA levels of TNF- $\alpha$ at $0,4,12$ and $24 \mathrm{~h}$ were measured by RT-qPCR. (D) The mRNA expression levels of TNF- $\alpha$ were significantly increased at 4,12 and $24 \mathrm{~h}$ compared with at $0 \mathrm{~h}(\mathrm{n}=4)$. (E) Inhibiting effect of $\mathrm{p} 65$ siRNA retroviruses on TNF- $\alpha$ secretion assessed by ELISA in THP-1 cells stimulated by LPS The THP-1/p65(-) and THP-1/siControl cells were treated with LPS $(0.1 \mathrm{~g} / \mathrm{ml})$ and secretory levels of TNF- $\alpha$ at $0,12,24$ and $48 \mathrm{~h}$ were measured by ELISA. Treatment with LPS resulted in a significant increase in the secretion of TNF- $\alpha$ at 12, 24 and $48 \mathrm{~h}$ in THP-1/M/siControl cells. However, the secretion of TNF- $\alpha$ sustained a lower level and there was no significant difference at $0,12,24$ and $48 \mathrm{~h}$ in THP-1/M/p65(-) cells $(\mathrm{n}=5)$. Data are expressed as the mean \pm standard deviation. "P<0.05 vs. 0 h. THP-1/p65(-) cells, THP-1 cells infected with p65 siRNA2 retroviruses; THP-1/siControl cells, THP-1 cells infected with siControl retroviruses. siRNA, small interfering RNA; TNF- $\alpha$, tumor necrosis factor- $\alpha$; LPS, lipopolysaccharide.

release stimulated by LPS, RT-qPCR was used to detect the expression of IL-1 $\beta$ in THP-1 cells. The level of IL-1 $\beta$ mRNA in THP-1/p65(-) and THP-1/siControl cells stimulated by LPS $(0.1 \mu \mathrm{g} / \mathrm{ml})$ at $0,4,8,12$ and $24 \mathrm{~h}$ is presented in Fig. 3. Statistical analysis revealed that the mRNA expression levels of p65 was significantly decreased at $12 \mathrm{~h}$ and $24 \mathrm{~h}$ in THP-1/p65(-) cells following stimulation with LPS, while increased at $12 \mathrm{~h}$ and $24 \mathrm{~h}$ in THP-1/siControl cells (Fig. 3B and D).

To further evaluate whether $\mathrm{p} 65$ siRNA retroviruses could suppress IL-1 $\beta$ production, ELISA was used to measure the secretion of IL-1 $\beta$ in THP-1/p65(-) and THP-1/siControl cells stimulated by LPS. As presented in Fig. 3E, treatment with LPS resulted in a significant increase in the secretion of IL- $1 \beta$ at $24 \mathrm{~h}$ and $48 \mathrm{~h}$ in THP-1/siControl cells. However, the secretion of IL-1 $\beta$ sustained a lower level and there was no significant difference at $0 \mathrm{~h}, 12 \mathrm{~h}, 24 \mathrm{~h}$ and $48 \mathrm{~h}$ in THP-1/p65(-) cells following stimulation with LPS (Fig. 3E).

Inhibition of proinflammatory cytokine TNF- $\alpha$ release by p65 siRNA retroviruses. To explore the effect of p65 siRNA retroviruses on the production of TNF- $\alpha$, THP-1 differentiated macrophage-like (THP-1/M) cells were used. When the THP-1 cells were pretreated with PMA $(100 \mathrm{nM} / \mathrm{ml})$ for $48 \mathrm{~h}$, the THP-1 cells were almost completely induced to differentiate into macrophage-like cells (Fig. 4).

The level of TNF- $\alpha$ mRNA in THP-1/M/p65(-) and THP- $1 / \mathrm{M} / \mathrm{siC}$ Control cells stimulated by LPS $(0.1 \mu \mathrm{g} / \mathrm{ml})$ at 0 , 4, 12 and $24 \mathrm{~h}$ was presented in Fig. 4A and C, as measured by RT-qPCR. Statistical analysis revealed that the mRNA expression levels of TNF- $\alpha$ was significantly decreased in THP-1/M/p65(-) cells at 4, 12 and $24 \mathrm{~h}$ stimulated by LPS, while increased in THP-1/M/siControl cells at 4, 12 and $24 \mathrm{~h}$ stimulated by LPS (Fig. 4B and D).

In addition, to confirm whether the inhibition of TNF- $\alpha$ mRNA correspond to a decrease in TNF- $\alpha$ protein, the secretion of TNF- $\alpha$ in THP-1/M/p65(-) and THP-1/M/siControl cells stimulated by LPS $(0.1 \mu \mathrm{g} / \mathrm{ml})$ was measured by ELISA. As demonstrated in Fig. 4E, treatment with LPS resulted in a significant increase in the secretion of TNF- $\alpha$ at 12, 24 and $48 \mathrm{~h}$ in THP-1/M/siControl cells. However, the secretion of 
TNF- $\alpha$ sustained a lower level and there was no significant difference at $0,12,24$ and $48 \mathrm{~h}$ in THP-1/M/p65(-) cells stimulated by LPS (Fig. 4E).

\section{Discussion}

ALI is a condition of acute respiratory failure, characterized by diffuse pulmonary infiltrates and severe hypoxemia (6). During ALI, the acute phase of inflammation induces the recruitment of activated inflammatory cells, including macrophages and lymphocytes, to the damaged lesions (7). Macrophages and lymphocytes are circulating immune cells that serve a crucial role in secreting proinflammatory cytokines and inactivating inflammatory mediators in the ischemic region (8).

$\mathrm{NF}-\kappa \mathrm{B}$ is a critical signal transcription factor for regulating immune and inflammatory responses (9). Importantly, the activity of NF- $\mathrm{NB}$ is regulated by its subcellular localization, and NF- $\kappa B$ is retained in the cytosol when bound to its inhibitor, I $\mathrm{KB}$. Activation of the I $\mathrm{B}$ proteins, which can be induced by a variety of stimuli, such as pro-inflammatory cytokines, allows $\mathrm{NF}-\kappa \mathrm{B}$ to be released from $\mathrm{I} \kappa \mathrm{B}$ and translocate to the nucleus where it can initiate transcription by binding to numerous specific gene promoter elements. The activation of the nuclear transcription factor $\mathrm{NF}-\kappa \mathrm{B}$ is closely associated with the excessive release of pro-inflammatory and inflammatory factors, such as TNF- $\alpha$ and IL- $1 \beta$ (10).

IL-1 $\beta$ is a member of inflammatory factors that is implicated in the pathogenesis of acute respiratory distress syndrome. It has been reported that IL-1 $\beta$ is one of the most biologically active cytokines in early phase of ALI, which is elevated in plasma, and that IL-1 $\beta$ is a potent inducer of lung which causes release of a variety of pro-inflammatory cytokines, such as monocyte chemotactic protein-1, macrophage inflammatory protein-1, IL-6 and IL-8 with subsequent recruitment of inflammatory cells into the airspaces as well as being able to alter endothelial-epithelial barrier permeability and fluid transport leading to edema (11). TNF- $\alpha$, a pro-inflammatory cytokine, is secreted in the pulmonary tissue by activated immune cells, which control the inflammatory process and accelerate secondary inflammatory processes by inducing inflammatory molecules, such as intercellular adhesion molecules, vascular cell adhesion molecules- 1 and selectin $(12,13)$. TNF- $\alpha$ is also responsible for the accumulation of inflammatory cells in the peripheral nucleus of pulmonary tissue, and it induces a second inflammatory response.

Several studies have proven that the inhibition of $\mathrm{NF}-\kappa \mathrm{B}$ activity leads to the reduction of the excessive release of inflammatory factors and may be a potential method for the clinical treatment of ALI $(14,15)$. However, an effective drug target to inhibit NF- $\mathrm{KB}$ has not been reported so far. RNA interference, which was first identified in Caenorhabditis elegans in 1998 , is a process of sequence-specific, post-transcriptional gene silencing in animals and plants, initiated by siRNA homologous in sequence to the silenced gene. RNA interference technique is now extensively employed in genetic engineering as a simple and effective gene knockdown tool $(16,17)$. The results demonstrated that p65 siRNA could significantly suppress the expression of $\mathrm{NF}-\kappa \mathrm{B}$ p $65 \mathrm{mRNA}$ and protein level, which confirmed that p65 siRNA could significantly inhibit the activity of $\mathrm{NF}-\kappa \mathrm{B}$.
As the NF- $\kappa \mathrm{B}$ signaling pathway is activated during ALI, the authors also investigated the effect of siRNA retroviruses

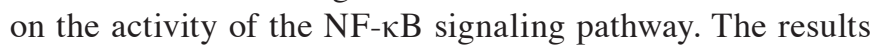
showed that the expression level of NF- $\kappa$ B p65 mRNA and protein significant decreased in THP-1 cells infected by $\mathrm{p} 65$ siRNA retroviruses, which indicated that p65 siRNA may inhibit the expression of NF- $\mathrm{NB}$ p65.

Furthermore, the authors detected the effect of siRNA retroviruses on the release of inflammatory cytokines in THP-1 and THP-1/M cells stimulated by LPS. LPS, a component of the outer membrane of Gram-negative bacteria, is considered to be the most potent activator of monocytes and macrophages. Monocytes and macrophages serve an essential role in inflammation and mobilization of the host defense against bacterial infection (18).

As a result, the expression levels of IL- $1 \beta$ and TNF- $\alpha$ mRNA and secreted protein were significantly increased in THP-1 and THP-1/M cells, which suggested that LPS may promoted the release of inflammation cytokines, such as IL- $1 \beta$ and TNF- $\alpha$. For the siRNA group, the results indicated that IL- $1 \beta$ and TNF- $\alpha$ mRNA expression levels was decreased, while the secreted protein expression levels exhibited no significant difference at different times in THP-1/p65(-) cells stimulated by LPS. The authors speculated that the protein secretion levels of IL-1 $\beta$ and TNF- $\alpha$ were very low without LPS stimulation, so the p65 siRNA may only inhibit the release of IL- $1 \beta$ and TNF- $\alpha$ protein secretion stimulated by LPS, rather than reduce the expression levels of secreted protein in THP-1 cells.

The results proved that $\mathrm{NF}-\kappa \mathrm{B}$ serves an essential role in regulating the release of inflammatory factors. The inhibition of the excessive release of inflammatory factors through $\mathrm{NF}-\kappa \mathrm{B}$ signal pathway may be an important method for the clinical treatment of ALI.

In summary, the results demonstrated that suppressing the expression of the NF- $\mathrm{NB}$ signaling pathway through $\mathrm{NF}-\kappa \mathrm{B}$ p65 siRNA causes an inhibition to release of inflammatory factors induced by LPS. The results suggested that disruption of the NF- $\kappa \mathrm{B}$ signaling pathway represents an opportunity for rational drug design for ALI prevention or treatment. These insights may help develop NF- $\kappa \mathrm{B}$ activity based pharmacological strategies to regulate inflammation but further study is required in vivo.

\section{References}

1. Wheeler AP and Bernard GR: Acute lung injury and the acute respiratory distress syndrome: A clinical review. Lancet 369: 1553-1564, 2007.

2. Kong MY, Gaggar A, Li Y, Winkler M, Blalock JE and Clancy JP: Matrix metalloproteinase activity in pediatric acute lung injury. Int J Med Sci 6: 9-17, 2009.

3. Al-Harbi NO, Imam F, Al-Harbi MM, Ansari MA, Zoheir KM, Korashy HM, Sayed-Ahmed MM, Attia SM, Shabanah OA and Ahmad SF: Dexamethasone attenuates LPS-induced acute lung injury through inhibition of NF- $\mathrm{NB}, \mathrm{COX}-2$, and Pro-inflammatory mediators. Immunol Invest 45: 349-369, 2016.

4. Wu CT, Zhu GF, Zhao JH, Zhang XF, Jin LY and Yan SF: Effect of retroviral vector mediating RNA interference on the release of tumor necrosis factor-alpha in lipopolysaccharide-stimulating macrophage. Zhonghua Yi Xue Za Zhi 90: 1283-1287, 2010 (In Chinese).

5. Livak KJ and Schmittgen TD: Analysis of relative gene expression data using real-time quantitative PCR and the 2(-Delta Delta C(T)) method. Methods 25: 402-408, 2001. 
6. Zhang X, Sun CY, Zhang YB, Guo HZ, Feng XX, Peng SZ, Yuan J, Zheng RB, Chen WP, Su ZR and Huang XD: Kegan Liyan oral liquid ameliorates lipopolysaccharide-induced acute lung injury through inhibition of TLR4-mediated NF- $\kappa \mathrm{B}$ signaling pathway and MMP-9 expression. J Ethnopharmacol 186: 91-102, 2016.

7. Kim YS, Hwang JW, Jang JH, Son S, Seo IB, Jeong JH, Kim EH, Moon SH, Jeon BT and Park PJ: Trapa japonica pericarp extract reduces LPS-induced inflammation in macrophages and acute lung injury in mice. Molecules 21: 392, 2016

8. Sun CY, Xu LQ, Zhang ZB, Chen CH, Huang YZ, Su ZQ, Guo HZ, Chen XY, Zhang X, Liu YH, et al: Protective effects of pogostone against LPS-induced acute lung injury in mice via regulation of Keap1-Nrf2/NF- $\kappa \mathrm{B}$ signaling pathways. Int Immunopharmacol 32: 55-61, 2016.

9. Qiu J, Yu L, Zhang X, Wu Q, Wang D, Wang X, Xia C and Feng H: Asiaticoside attenuates lipopolysaccharide-induced acute lung injury via down-regulation of NF- $\kappa \mathrm{B}$ signaling pathway. Int Immunopharmacol 26: 181-187, 2015.

10. Wang J, Liu YT, Xiao L, Zhu L, Wang Q and Yan T: Anti-inflammatory effects of apigenin in lipopolysaccharide-induced inflammatory in acute lung injury by suppressing COX-2 and NF- $\kappa$ B pathway. Inflammation 37: 2085-2090, 2014.

11. Yang L, Li D, Zhuo Y, Zhang S, Wang X and Gao H: Protective role of liriodendrin in sepsis-induced acute lung injury. Inflammation 39: 1805-1813, 2016.
12. Lucas SM, Rothwell NJ and Gibson RM: The role of inflammation in CNS injury and disease. Br J Pharmacol 147 (Suppl 1): S232-S240, 2006.

13. Nilupul Perera M, Ma HK, Arakawa S, Howells DW, Markus R, Rowe CC and Donnan GA: Inflammation following stroke. J Clin Neurosci 13: 1-8, 2006.

14. Liang D, Sun Y, Shen Y, Li F, Song X, Zhou E, Zhao F, Liu Z, Fu Y, Guo M, et al: Shikonin exerts anti-inflammatory effects in a murine model of lipopolysaccharide-induced acute lung injury by inhibiting the nuclear factor-kappaB signaling pathway. Int Immunopharmacol 16: 475-480, 2013.

15. Zhu T, Wang DX, Zhang W, Liao XQ, Guan X, Bo H, Sun JY, Huang NW, He J, Zhang YK, et al: Andrographolide protects against LPS-induced acute lung injury by inactivation of NF- $\kappa \mathrm{B}$. PLoS One 8: e56407, 2013.

16. Fire A, Xu S, Montgomery MK, Kostas SA, Driver SE and Mello CC: Potent and specific genetic interference by double-stranded RNA in Caenorhabditis elegans. Nature 391: 806-811, 1998

17. Elbashir SM, Harborth J, Lendeckel W, Yalcin A, Weber K and Tuschl T: Duplexes of 21-nucleotide RNAs mediate RNA interference in cultured mammalian cells. Nature 411: 494-498, 2001.

18. Greenlee-Wacker MC: Clearance of apoptotic neutrophils and resolution of inflammation. Immunol Rev 273: 357-370, 2016. 